\title{
Incremental versus Rapid Internationalisation of Firms: Results of Exploratory Investigation from Poland
}

\author{
Krzysztof Wach
}

\begin{abstract}
A B S T R A C T
Objective: The main objective of the article was to discuss the pace of internationalisation and its empirical verification among Polish firms taking into account two factors - strategic thinking and familiness of the studied firms.

Research Design \& Methods: The paper, apart from literature review and its critique, is based on results of a survey conducted among randomly selected 355 internationalised firms of different sizes from Poland.

Findings: Firms having an internationalisation strategy rather internationalise faster than these lacking such a strategy, taking into account the average number of years elapses from its founding to the first internationalisation. The empirical results show that the average time of internationalisation is shorter in case of family firms than non-family firms.
\end{abstract}

Implications \& Recommendations: Strategic thinking seems to be very important while going international. A well thought-out strategy can stimulate the whole process of internationalisation, so decision makers, especially entrepreneurs, should pay more attention to strategic aspects, even in early stages of development or early internationalisation.

Contribution \& Value Added: The article attempts to enrich the ongoing scientific discourse on the role of time and the pace of internationalisation by adding some evidence from Poland illustrating and verifying the links between strategic thinking as well as familiness of firms and the speed of internationalisation measured in years from the establishment of firms.

\begin{tabular}{|c|c|}
\hline Article type: & $\begin{array}{l}\text { research paper } \\
\text { born globals; international entrepreneurship; international business; } \\
\text { internationalisation; strategy; family firm }\end{array}$ \\
\hline JEL cod & Revised 11 December 2015 \\
\hline
\end{tabular}

\section{Suggested citation:}

Wach, K. (2015). Incremental versus Rapid Internationalisation of Firms: Results of Exploratory Investigation from Poland. Entrepreneurial Business and Economics Review, 3(4), 37-48. doi: 10.15678/EBER.2015.030403 


\section{INTRODUCTION}

There is an ongoing discourse on the role of time in the internationalisation process of firms (Ratajczak-Mrozek, 2015). There are usually two competitive perspectives. The first one, which is classical or traditional, states that the internationalisation process is incremental and the firm goes through various stages treating internationalisation as a slow process of excellence (international-by-stages), which is also based on the concept of exporting by learning (Wąsowska, Obloj, \& Ciszewska-Mlinarič, 2016). The second trend reveals internationalisation as a rapid or accelerated process and believes that some factors make that internationalisation is much more complex from the inception of the firm (international at founding).

Some scholars try to explain the internationalisation process of the firm by using various strategic management variables (Bell, Crick, \& Young, 2004). As it is evident in many studies that strategic thinking has impact on the international orientation of firms. This study tests this relationship in a Polish context to explore if and how planned or formalised strategies can influence the speed of internationalisation.

Various researchers have provided mixed evidence on how different factors facilitate or constrains internationalisation of family firms (Daszkiewicz \& Wach, 2014). Time seems to be one of the features that distinguishes the process of internationalisation of family and non-family businesses, there some empirical evidence for faster internationalisation (Popczyk, 2013), while some empirical results show the opposite trend (Wach, 2014). The current study tries to involve this factor into the ongoing discussion.

The article aims at discussing the pace of internationalisation through two basic theoretical perspectives and at empirically verifying the speed of internationalisation of Polish internationalised firms taking into account two factors - strategic thinking and familiness of the studied firms. The article includes the analysis of the literature and its critics as well as the discussion on empirical results based on a survey questionnaire conducted on the sample of 355 firms from Poland.

The first section of the paper includes the literature review on two main perspectives of the internationalisation time, namely the stages models based on the incremental internationalisation as well as the international entrepreneurship perspective expressed in the early and rapid internationalisation. The second section discusses the methodological assumptions of the empirical studies, among them the hypotheses, the research design and the sampling. The third sections elaborates on the empirical results of the survey and the statistical calculations, followed by the conclusions in typical layout consisting of final remarks, research limitations and suggestions for further studies.

\section{LITERATURE REVIEW}

There are various theoretical models explaining the phenomenon of internationalisation of firms. The beginnings of stages models, as the oldest ones in the theory of the internationalisation of the firm, go back to 1970s, when almost simultaneously Swedish and Finnish researchers used the behavioural theory of the firm to explain behaviours within internationalisation. The group of those theories is also defined as Nordic models (Ruzzier, Hisrich, \& Antoncic, 2006, p. 482), or learning models (Ibidem), but also process mod- 
els (Mejri \& Umemoto, 2010, p. 157), incremental ones (Coviello \& McAuley, 1996), sequentional ones (Wickramasekera \& Oczkowski, 2006, p. 52), the models of establishment order or establishment chain (Crick, Chaudhry, \& Batstone, 2001, p. 79), gradual ones (Morgan \& Katsikeas, 1997, p. 72), evolutionary (Ibidem) or process ones (process theories of internationalisation, PTI) (Schwens, Steinmetz, \& Kabst, 2010, p. 114). They are based on the phase (process) convention of firm development (organisational life cycle). Their common feature is sequential passing in the internationalisation process through various stages or phases which together create a set order, and each next stage is related to bigger commitment of the firm to international activities. In the literature of the subject there are several dozen stages models, each with different number of stages, but, as a rule, the initial stage is the activity on the domestic market.

Stages models belong to the mainstream of the internationalisation theory and are most frequently used in empirical research although they are not perfect concepts, which is almost equally often discussed in the literature of the subject. The main charge against them concerns sequentiality. Numerous authors argue that not every firm must go through all the stages, starting from the initial one and ending with the last one. In the literature of the subject we can also come across extreme opinions, such as, for example, Cavusgil's (1994, p. 18) view that gradual internationalisation is already dead, which was said in the context of the phenomena of born globals. The criticism of stages models boils down to the following controversies:

- not every business passes through all the stages of the establishment chain, in practice, leapfrogging or omitting some stages takes place (Cannon \& Willis, 1981);

- in practice, some firms apply either the path of accelerated internationalisation, as it takes place, for example, in the case of hidden champions, or they are international or even global from the very beginning (born globals) (Oviatt \& McDougall, 1994);

- stages models do not consider either the strategic approach of the management staff or entrepreneurial processes which in contemporary times seem crucial for the international growth (internationalisation) of the firm (Reid, 1981; Andersson, 2000);

- due to the specific character of services, stages models are not applicable to the analyses of internationalisation of service firms (Grőnroos, 1999, p. 292).

Few previous decades have caused that the global economy has undergone a dramatic change, and the "new economic landscape requires a combination of entrepreneurship, innovation, and internationalisation" (Hagen, Denicolai, \& Zucchella, 2014, p. 111). The concept of 'international entrepreneurship' (IE) came into being in late 1980s, however the theory of IE was developed in mid 1990s, mainly by McDougall (1989), who together with Oviatt developed this theory in the following years (Oviatt \& McDougall, 1994; McDougall, Shane, \& Oviatt, 1994). International entrepreneurship has been developing very intensively (Al-Aali \& Teece, 2014; Almor et al., 2014; Covin \& Miller, 2014; Hennart, 2014; Wach \& Wehrmann, 2014, pp. 9-22). International entrepreneurship, linking two research domains - entrepreneurship theory and international business theory (McDougall-Covin, Jones, \& Serapio, 2014; Zucchella \& Sciabini, 2007; Coviello, McDougall, \& Oviatt, 2011; Coviello, Jones, \& McDougall, 2014; Wach \& Wehrmann, 2014), is gradually beginning to emerge as the dominating approach within the internationalisation theory (the leading approach towards business internationalisation process) (Jones \& Coviello, 2011; Coviello, Jones, \& McDougall-Covin, 2014). International entre- 
preneurship specifically examines and prioritises the role of the entrepreneur as a key factor in the internationalisation process of the firm, especially of SMEs alongside the external environment and the entrepreneurial process constituting the triad of international entrepreneurship or entrepreneurial internationalisation (Daszkiewicz, 2014; Wach, 2015).

The globalisation processes and the increasing role of global players resulted in the reorientation from the business internationalisation processes (Johanson \& Vahlne, 1977; Johanson \& Vahlne, 2009) to business globalisation process (Vahlne \& Ivarsson, 2014, pp. 227-247), thus international entrepreneurship concept is currently included even in the traditional Uppsala model (Schweizer, Vahlne, \& Johanson, 2010). This is clearly illustrated by Hurmerinta-Peltomäki (2004, pp. 72-73), who tries to put main international entrepreneurship concepts on the internationalisation-globalisation scale starting from an instant exporter, or an international new venture, and resulted in globalized business activities (born globals as the global start-ups).

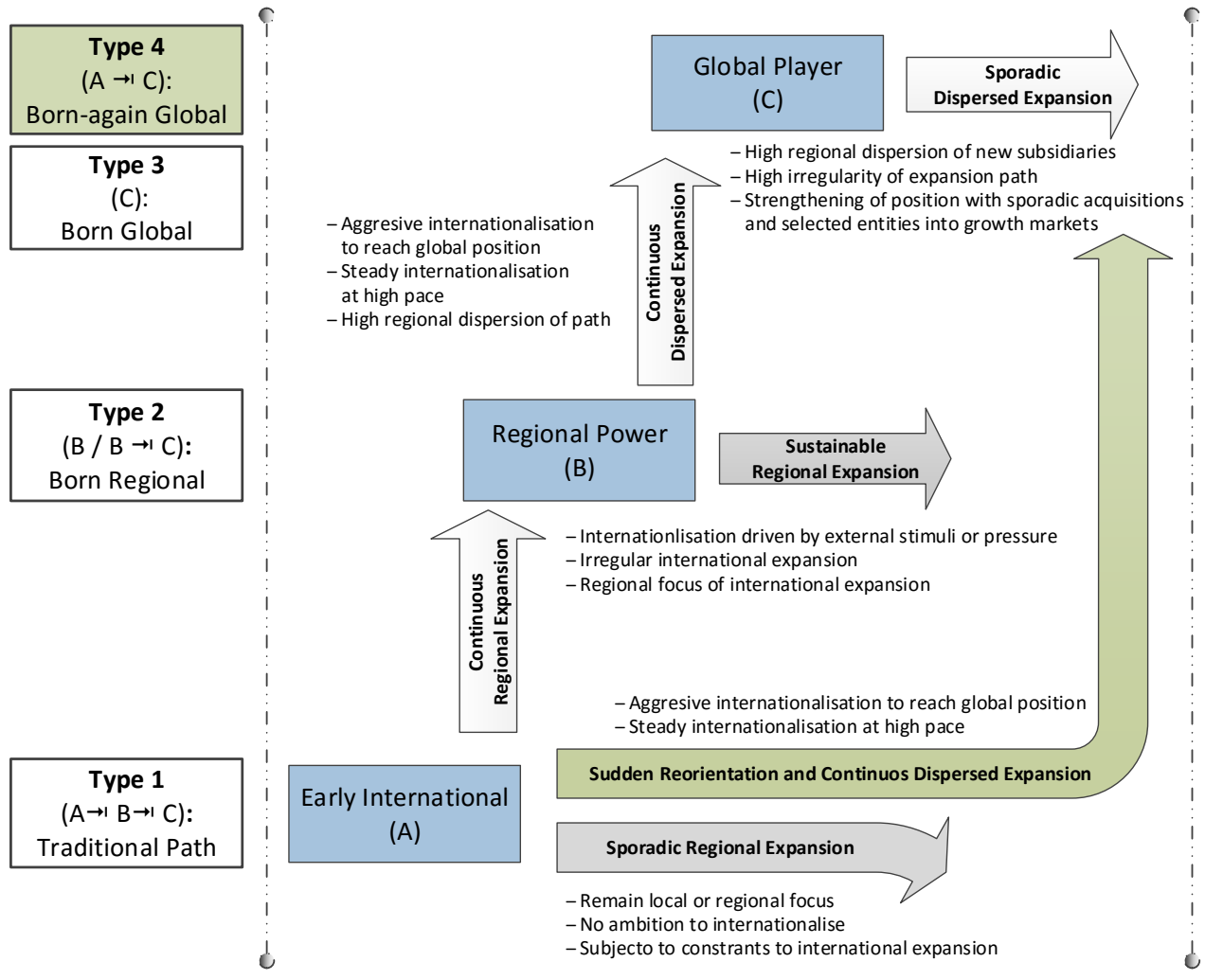

Figure 1. Four basic paths of internationalisation of the firm

Source: adapted and extended from Hutschenreuter, D'Aveni and Voll (2009, p. 65).

Hutschenreuter, D'Aveni and Voll (2009) identified three basic types (A, B, C) of internationalised firms (Figure 1), however it is worth extending the original model to four types $(1,2,3,4)$ of internationalisation paths. Firms that internationalise in a traditional 
path though stages according to U-model assumptions (Type 1). On the contrary to this concept there are born globals (Type 3), which are firms that internationalise early and rapidly, which treat the global market as their target business arena from their inception.

Furthermore, Hutschenreuter et al. (2009) noticed two more types, which are also discussed in the recent literature. Within international entrepreneurship at least two or three more groups of concepts are being developed which are worth noting. Accelerated internationalisation or rapid internationalisation models concern traditional SMEs which are not interested in operating on the global market from the very beginning, however, the pace of their internationalisation is high (Kalinic \& Forza, 2012). The other one is the concept of born regionals (Type 2) which are internationalised from the beginning, yet their scope concerns mainly the markets of neighbouring countries, whereby with time some of them develop their international activities (Hashai \& Almor, 2004).

The concept of born-again globals (Type 4) by Bell, McNaugton, Young and Crick (2003) is also interesting and popular in the literature and can be treated as a supplementary fourth path. It concerns businesses initially operating on the domestic market, however, as a result of noticing opportunities on foreign markets their rapid internationalisation takes place, running from the moment of their transformation in an analogous manner as among born globals. Generally, these are often firms which come from traditional industries.

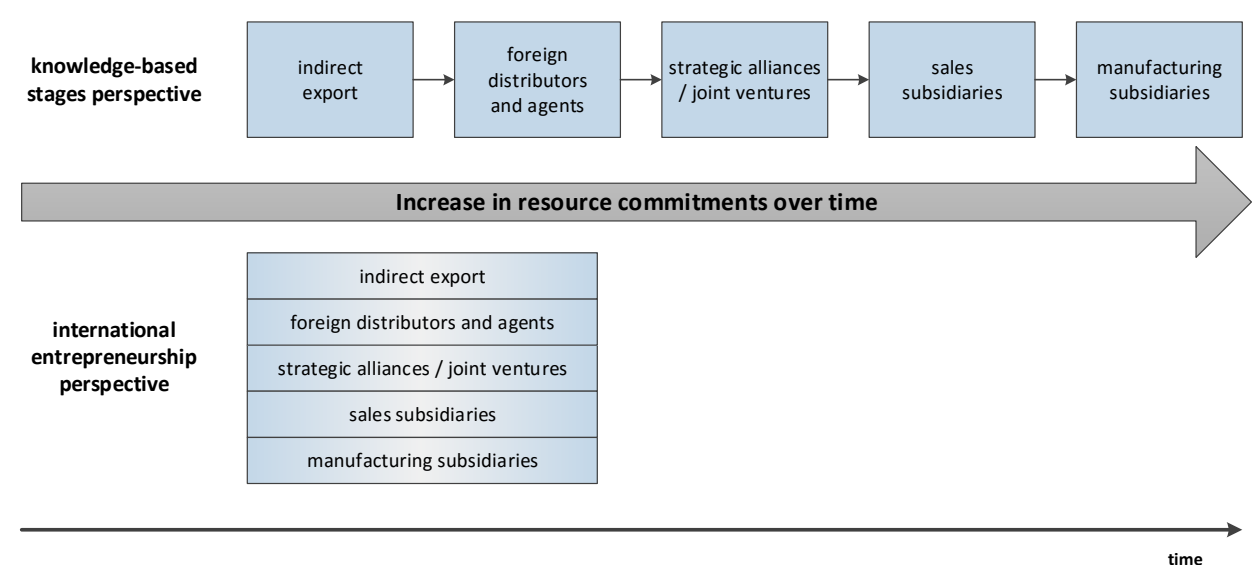

Figure 2. Time and internationalisation from two opposite theoretical perspectives Source: adapted from Melén and Nordman (2009, p. 246).

Melén and Nordman (2009, p. 246) emphasized that stages models based on the concept of accumulation and implementation of knowledge differ considerably from international entrepreneurship models, as they are based on different research assumptions. The process theory is based on a phased incremental change, which is manifested in the use of more advanced entry modes into foreign markets with time, and studies implemented this perspective are dynamic (such investigations usually use case studies showing the process of internationalisation of the firm with time). By contrast, the research studies rooted in international entrepreneurship usually do not focus on the further or ongoing internationalisation process, which is the domain of the process theory (Figure 2), but they try to show the internationalisation process through the entrepre- 
neurial prim, what is rather in static terms. The perspective of international entrepreneurship (nota bene also based on a case study method) focuses on one hand on the phenomenon of accelerated and early internationalisation, and on the other hand, on the use of entrepreneurial mechanisms across borders.

\section{MATERIAL AND METHODS}

The article contains the results of empirical studies that have been conducted under the grant OPUS 4 carried out in 2013-2016 at the Faculty of Economics and International Relations, Cracow University of Economics, and funded by the National Science Centre (NCN).

The main objective of the study is to discuss the pace of internationalisation and its empirical verification among Polish firms taking into account two factors - strategic thinking and familiness of the studied firms.

The sample was selected on the basis of the companies registered in Poland in the REGON register, of which 7100 companies were randomly selected to which the questionnaire was mailed. Of these companies, only 355 agreed to take part in the study. The sample contained only internationalised firms (which are at least exporters). The sample comprised of firms of all sizes. A theoretical return rate was 5\%, however among 7100 randomly selected companies some of them were not internationalised or changed their postal address and/or their telephone number. The selected population consisted of 3313 firms, and the final study sample was de facto $10.7 \%$.

In order to gather empirical material, a quantitative research method was applied. The main research method for non-experimental quantitative research, which was applied in this research project, was a research survey using a questionnaire for data collection with the intent of generalizing from a sample to a population. The survey was conducted in early 2015.

Computer-assisted telephone interviewing (CATI) was applied as the main survey method. This means that respondents (usually members of top management teams) answered the questions by phone while speaking to the pollster.

Managerial perceptions of firm-level variables are often used in entrepreneurship research (Naman \& Slevin, 1993), and these perceptions can be obtained from interviews or from surveys using questionnaires. "One potential advantage of perceptual approaches is a relatively high level of validity because researchers can pose questions that address directly the underlying nature of a construct" (Lyon et al., 2000, p. 1058).

The research hypotheses to be tested in this research study are as follows:

H1. Firms having an internationalisation strategy internationalize faster than those which do not have such a strategy.

In the literature there is a consensus that a business strategy impacts the international orientation of firms (Bell, Crick, \& Yung, 2004), nevertheless it is necessary to study this problem in details. It can affect various aspects of internationalisation, including the pace/speed of internationalisation. So it seems to be interesting to check this relationship (strategy and pace of internationalisation).

H2:

The average time of internationalisation measured from the establishment is the same for family and non-family firms. 
There is an ongoing dispute in the literature and a lack of clear evidence. Not only globally, but even in the Polish context, there is some empirical evidence for faster internationalisation of family firms (Popczyk, 2013), while some empirical results show the opposite trend (Wach, 2014).

The study uses six different variables. The internationalization was measured by four different measures, namely:

- transnationality index (TNI) calculated as the average of foreign assets, sales and employment to the total ones and being expressed as a percentage (from 0 to $100 \%$ );

- internationalization speed or pace (INT_SPEED) stating how many years passed between the establishment of the firms and the first internationalisation of the firm (measured in years);

- internationalisation scope (INT_SCOPE) measuring on many foreign markets the firm operates.

The foreign ecological environment was measured by using 7-point Likert's scale (from 1 - hampering to 7 - stimulating). This study uses also various control variables, among them: being a family firm (0/1), being a born global $(0 / 1)$, having an internationalisation strategy $(0 / 1)$.

The statistical calculations were made by the use of the statistical software Statisti$\mathrm{ca}^{\circledR} \mathrm{PL}$ v. 12.5. In the empirical study, the level of the statistical significance (alpha or $\alpha$ ) for statistical hypotheses testing was considered as 0.05 . Apart from basic descriptive statistics, in order to verify the assumed hypotheses the following interferential statistical tests were applied: the Mann-Whitney $U$ test; Student's t test, as well as the Chisquared independent test.

\section{RESULTS AND DISCUSSION}

Only one in five surveyed firms declares to have the formalized internationalisation strategy, and more than half of the firms did not have any strategy either formal, or even informal. Using the independence Chi-squared test $(26.47618, d f=3, p=0.0001$ ), we can conclude that there is a relationship between the internationalisation strategy and the size of the firms. The larger the firms are, the more often they have an internationalisation strategy (26.0\% micro, 39.9\% small, 55.7\% medium-sized, $71.7 \%$ large enterprises). The Cramer's $V$ value (0.27) testifies rather moderate strength of the relationship between the size of the firm and an internationalisation strategy implementation.

There are statistically significant differences in the pace of internationalisation among firms with and without an internationalisation strategy (H1), although it should be noted that not with a typical, but with an acceptable level of significance $(t=1.6855$, $d f=342, p=0.092$ ). The average rate of internationalisation of firms having an internationalisation strategy is lower and is over 5 years, while in other companies, it is almost 8 years.

From the theoretical perspective, the pace of internationalisation is closely associated with the firms referred to as born globals, the time limit, according to the literature, is in general 3 years (however other limits also occur). The two-dimensional distribution taking into account two variables, namely the internationalisation strategy and born globals, exposes the lack of any statistically significant differentiations. The distributions 
of observations are in fact almost equal (variables are independent), as indeed it is also confirmed by the nonparametric chi-squared test $(0.10, d f=1, p=0.75)$.

The calculations of Pearson's linear correlation can put also a new overview onto the pace of the internationalisation of the studied firms and the following conclusions can be drawn:

- The speed of internationalisation is correlated weakly to the internationalisation scope $(r=0.25, p<0.05)$.

- There is a weak negative correlation between the speed of internationalisation and the level of the internationalisation measured by TNI $(r=-0.2, p<0.05)$. The more slowly the firm internationalizes, the more internationalized it is.

It seems useful to find some factors why studied firms internationalize faster and earlier than others. The collected empirical data and statistical calculations also allow to draw other valuable cognitive conclusions. Ecological awareness of foreign consumers and environmental regulations being in force outside Poland stimulate firms to internationalize more quickly and early (measured by the speed of the internationalisation process), which was confirmed by the Mann-Whitney $U$ statistics $(p=0.018)$. There are two ways of explanations these results. Polish born globals can run away from the domestic ecological and environmental standards into foreign markets, where such regulations are more liberal (e.g. Eastern markets), which should be summaries as a push factor (Daszkiewicz \& Wach, 2014). The second explanation is much more optimistic. Polish born globals are so well prepared to high ecological and environmental standards that it stimulates their internationalisation into other countries (i.e. Western markets), and such a situation is a typical pull factor. In order to answer this controversies, it is necessary to check into what foreign markets the studied firms entry, but unfortunately the questionnaire didn't include such a question.

Concerning the second hypothesis $(\mathrm{H} 2)$, it was proved that the family firms internationalize faster than non-family firms $(t=2.1, d f=342, p=0.03)$. The average pace of internationalisation of family firms is 4.6 years, while for non-family firms it is 8.1 years on the average. The results are very interesting as there is an unsolved ongoing discussion in the literature, even in Poland. Some empirical results, conducted previously in Poland, prove it (Popczyk, 2013), while others are against such a relationship (Wach, 2014).

\section{CONCLUSIONS}

Some basic conclusions based on the survey results and statistical calculations can be drawn, however they must be treated as one of the empirical evidence on the map of various empirical results from Poland.

The hypothesis $\mathrm{H} 1$ was confirmed. Firms having an internationalisation strategy rather internationalise faster than these lacking such a strategy, taking into account the average number of years elapsed from its founding to the first internationalisation. In dichotomous terms taking into account born globals (up to 3 years) and slower internationals (longer than 3 years), such a relationship cannot be indicated on the basis of the empirical results. Strategic thinking seems to be very important while going international. A well thought-out strategy can stimulate the process of internationalisation. There- 
fore, it is suggested that decision makers, especially entrepreneurs, should pay more attention to strategic aspects, even in early stages of development or early internationalisation.

The hypothesis $\mathrm{H} 2$ was rejected as it was proved that the average time of internationalisation measured from the establishment is shorter in case of family firms than non-family firms. On the average the investigated family firms internationalised within less than 5 years since their establishment. It is in line with empirical results of Popczyk (2013, p. 10 and 215), but against the previous studies of Wach (2014). Nevertheless, further detailed research using a much wider sampling of internationalised family firms is needed in order to present more detailed and precise conclusions.

Like any study, especially the empirical investigations, the analyses presented in this article have their research limitations. They are mainly conditioned by sampling, applied measures and analytical tests. The questionnaire primarily necessitated the use of managerial perception, that is not operated on quantifiable data, but only on the perception of the studied management staff (which is natural in questionnaires), hence it is not possible to absolutise the obtained results. Further in-depth studies are needed.

Results presented in this article are a merely starting point for further detailed analyses and investigations. It seems reasonable to research into the various determinants of the speed of internationalisation taking the great varieties of internal and external factors, especially the factors stimulating born globals.

\section{REFERENCES}

Al-Aali, A., \& Teece, D.J. (2014). International Entrepreneurship and the Theory of the (Long-Lived) International Firm: A Capabilities Perspective. Entrepreneurship Theory and Practice, 38(1), 95116. doi: 10.1111/etap.12077

Almor, T., Tarba, Sh.Y., \& Margalit, A. (2014). Maturing, Technology-Based, Born-Global Companies: Surviving Through Mergers and Acquisitions. Management International Review, 54, 421444. doi: 10.1007/s11575-014-0212-9

Andersson, S. (2000). The Internationalisation of the Firm from and Entrepreneurial Perspective. International Studies of Management \& Organization, 30(1), 63-93.

Bell, J., Crick, D., \& Young, S. (2004). Small Firm Internationalisation and Business Strategy: An Exploratory Study of 'Knowledge-intensive' and 'Traditional' Manufacturing Firms in the UK. International Small Business Journal, 22(1), 23-56.

Bell, J., McNaughton, S., Young, S., \& Crick, D. (2003). Towards Integrative Model of Small Firm Internationalisation. Journal of International Entrepreneurship, 1(4), 339-362.

Cannon, T., \& Willis, M. (1981). The Smaller Firm in International Trade. European Small Business Journal, 1(3), 45-55.

Cavusgil, S.T. (1994). A Quit Revolution in Australian Exporters. Marketing News, 28(11), 18-21.

Coviello, N.E., Jones, M.V., \& McDougall-Covin, P. (2014). Is International Entrepreneurship research a viable spin-off from its parent disciplines? In A. Fayolle \& P. Riot (Eds.), Institutionalization of Entrepreneurship: Hopes and Pitfalls for Entrepreneurship Research. Routledge.

Coviello, N.E., \& McAuley, A. (1999). Internationalisation and the Smaller Firm: A Review of Contemporary Empirical Research. Management International Review, 39(3), 223-256. 
Covin, J.G., \& Miller, D. (2014). International Entrepreneurial Orientation: Conceptual Considerations, Research Themes, Measurement Issues, and Future Research Directions. Entrepreneurship Theory and Practice, 38(1), 11-44. doi: 10.1111/etap.12027

Crick, D., Chaudhry, Sh., \& Batstone, S. (2001). An Investigation into the Overseas Expansion of Small Asian-Owned U.K. Firms. Small Business Economics, 16(2), 75-94.

Daszkiewicz, N. (2014). Internacjonalizacja polskich przedsiębiorstw rodzinnych z perspektywy przedsiębiorczości międzynarodowej. Przedsiębiorczość i Zarzq̨dzanie, XV(7[1]), 243-251.

Daszkiewicz, N., \& Wach, K. (2014). Motives for Going International and Entry Modes of Family Firms in Poland. Journal of Intercultural Management, 6(2), 5-18.

Grőnroos, C. (1999). Internationalisation Strategies for Services. Journal of Service Marketing, 13(45), 290-297.

Hagen, B., Denicolai, S., \& Zuchella, A. (2014). International entrepreneurship at the crossroads between innovation and internationalisation. Journal of International Entrepreneurship, 12(2), 111-114.

Hashai, N., \& Almor, T. (2004). Gradually Internationalizing 'Born Global' Firms: An Oxymoron?. International Business Review, 13(4), 465-483.

Hennart, J.-F. (2014). The Accidental Internationalists: A Theory of Born Global. Entrepreneurship Theory and Practice, 38(1), 117-135. doi: 10.1111/etap.12076

Hurmerinta-Peltomäki, L. (2004). Conceptual and Methodological Underpinnings in the Study of Rapid Internationalizers (chapter 3). In M.V. Jones \& P. Dimitratos (Eds.), Emerging Paradigms in International Entrepreneurship. The McGill International Entrepreneurship series. Cheltenham, UK - Northampton, MA: Edward Elgar.

Hutschenreuter, T., D’Aveni, R., \& Voll, J. (2009). Temporal and Geographical Patterns of Internationalisation - an Exploratory Analysis. Multinational Business Reviews, 17(4), 45-76.

Johanson, J., \& Vahlne, J.-E. (1977). The Internationalisation Process of the Firm: A Model of Knowledge Development and Increasing Foreign Commitments. Journal of International Business Studies, 8(1), 23-32.

Johanson, J., \& Vahlne, J.-E. (2009). The Uppsala Internationalisation Process Model Revisited: From Liability of Foreignneess to Liability of Outsidership. Journal of International Business Studies, 40(9), 1411-1431.

Jones, N.V., Coviello, N., \& Tang, Y.K. (2011). International Entrepreneurship Research (1989-2009): A Domain Ontology and Thematic Analysis. Journal of Business Venturing, 26(6), 632-659.

Kalinic, I., \& Forza, C. (2012). Rapid Internationalisation of Traditional SMEs: Between Gradualist Models and Born Globals. International Business Review, 21(4), 694-707.

Lyon, D.W., Lumpkin, G.T., \& Dess, G.G. (2000). Enhancing Entrepreneurial Orientation Research: Operationalizing and Measuring a Key Strategic Decision Making Process. Journal of Management, 26(5), 1055-1085. doi: 10.1177/014920630002600503

McDougall, P.P. (1989). International versus Domestic Entrepreneurship: New Venture Strategic Behavior and Industry Structure. Journal of Business Venturing, 4(6), 387-400. doi: 10.1016/0883-9026(89)90009-8

McDougall, P.P., Shane, S., \& Oviatt, B.M. (1994). Explaining the Formation of International New Ventures: The Limits of Theories from International Business Research. Journal of Business Venturing, 9(6), 469-487. doi: 10.1016/0883-9026(94)90017-5

McDougall-Covin, P., Jones, M.V., \& Serapio, M.G. (2014). High-Potential Concepts, Phenomena, and Theories for the Advancement of Entrepreneurship Research. Entrepreneurship Theory and Practice, 38(1), 1-10. doi: 10.1111/etap.12090 
Mejri, K., \& Umemoto, K. (2010). Small- and Medium-Sized Enterprise Internationalisation: Towards the Knowledge-Based Model. Journal of International Entrepreneurship, 8(2), 156-167.

Melén, S., \& Nordman, E.R. (2009). The internationalisation modes of Born Globals: A longitudinal study. European Management Journal, 27(4), 243-254.

Morgan, R.E., \& Katsikeas, C.S. (1997). Theories of International Trade, Foreign Direct Investment and Firm Interntionalization: A Criique. Management Decision, 35(1), 68-78.

Naman, J.L., \& Slevin, D.P. (1993). Entrepreneurship and the concept of fit: A model and empirical tests. Strategic Management Journal, 14(2), 137-153. doi: 10.1002/smj.4250140205

Oviatt B.M., \& McDougall, P.P. (1994). Towards a Theory of International New Ventures. Journal of International Business Studies, 25(1), 44-64.

Popczyk, W. (2013). Przedsiębiorstwa rodzinne w otoczeniu globalnym. Analiza porównawcza ekspansji międzynarodowej firm rodzinnych i nierodzinnych z rynku NewConnect. Łódź: Wydawnictwo Uniwersytetu Łódzkiego.

Ratajczak-Mrozek, M. (2015). Czas w badaniach nad internacjonalizacją przedsiębiorstw. Gospodarka Narodowa, LXXXV/XXVI(4), 49-67.

Reid, S.D. (1981). The Decision-Maker and Export Entry and Expansion. Journal of International Business Studies, 12(2), 101-112.

Ruzzier, M., Hisrich, R.D., \& Antoncic, B. (2006). SME Internationalisation Research: Past, Present, and Future. Journal of Small Business and Enterprise Development, 13(4), 476-497.

Schweizer, R., Vahlne, J.-E., \& Johanson, J. (2010). Internationalisation as an Entrepreneurial Process. Journal of International Entrepreneurship, 8(4), 343-370.

Schwens, Ch., Steinmetz, H., \& Kabst, R. (2010). Growth and Internationalisation: Renewable Energy and New Technology-Based Firms. In A. Gerybadze, U. Hommel, H.W. Reiners, \& D. Thomaschewski (Eds.), Innovation and International Corporate Growth (pp. 113-123). Heidelberg-New York: Springer.

Vahlne, J.-E., \& Ivarsson, I. (2014). The globalization of Swedish MNEs: Empirical evidence and theoretical explanations. Journal of International Business Studies, 45(3), 227-247.

Wach, K. (2014). Familiness and Born Globals: Rapid Internationalisation among Polish Family Firms. Journal of Intercultural Management, 6(3), 177-186.

Wach, K. (2015). Entrepreneurial Orientation and Business Internationalisation Process: The Theoretical Foundations of International Entrepreneurship. Entrepreneurial Business and Economics Review, 3(2), 9-24. doi: 10.15678/EBER.2015.030202

Wach, K., \& Wehrmann, C. (2014). Entrepreneurship in International Business: International Entrepreneurship as the Intersection of Two Fields (chapter 1). In A.S. Gubik \& K. Wach (Eds.), International Entrepreneurship and Corporate Growth in Visegrad Countries (pp. 9-22). Miskolc: University of Miskolc.

Wąsowska, A., Obloj, K., \& Ciszewska-Mlinarič, M. (2016 - in press). Virtuous and Vicious Learning Cycles in the Internationalisation of Emerging Market Firms. European Journal of International Management, 10(1), 105-125. doi: 10.1504/EJIM.2016.073964

Wickramasekera, R., \& Oczkowski, E. (2006). Stage Models Re-visited: A Measure of the Stage of Internationalisation of a Firm. Management International Review, 46(1), 39-55.

Zucchella, A., \& Scabini, P. (2007). International Entrepreneurship - Theoretical Foundations and Practice. New York: Palgrave Macmillan. 


\section{Author}

\section{Krzysztof Wach}

Associate Professor (Prof. UEK) of the Cracow University of Economics (Poland). Habilitated doctor of economics (DEcon), PhD in management, specialist in international entrepreneurship, author of several books and over 150 scientific articles, editor-in-chief of the scientific quarterly Entrepreneurial Business and Economics Review, member of editorial boards of several scientific journals, including Business Excellence (Croatia), Studia Negotia (Romania), Entrepreneurship - Education (Poland); in the years 2012-2014 an OECD and the European Commission national expert for entrepreneurship, participant of various international education and research projects (e.g. Jean Monnet, EU-US Atlantis, International Visegrad Fund IVF, Central European Initiative CEI), visiting professor in various American and European universities, including Grand Valley State University (Grand Rapids, USA), Roosevelt University (Chicago, USA), Loyola University Chicago (Chicago, USA), University of Detroit Mercy (Detroit, USA), Northumbria University (Newcastle, UK), University College London (UK), Technical University of Cartagena (Cartagena, Spain), FH Joanneum (Graz, Austria), University of Zagreb (Croatia).

\section{Correspondence to:}

Prof. UEK dr hab. Krzysztof Wach

Cracow University of Economics

Faculty of Economics and International Relations

Department of Entrepreneurship and Innovation

31-510 Kraków, ul. Rakowicka 27, Poland

wachk@uek.krakow.pl

\section{Acknowledgements and Financial Disclosure}

The article came into being within the research project OPUS 4 entitled Behaviour of Polish firms in the process of internationalisation from the international entrepreneurship perspective, which has been funded by the National Science Centre (NCN) on the basis of the decision no. DEC2012/07/B/HS4/00701 in the years 2013-2016.

\section{Copyright and License}

This article is published under the terms of the Creative Commons Attribution - NonCommercial - NoDerivs (CC BY-NC-ND 3.0) License http://creativecommons.org/licenses/by-nc-nd/3.0/ 